\title{
Coastal City Environmental Protection and Governance: Reviewing Residents' Recycling of Renewable Resources for Waste Management in China
}

\author{
Sheng-Feng Shih ${ }^{1}$, Meng-Chen $\operatorname{Lin}^{2}$, and Li-Fen $\operatorname{Lin}^{1, *}$ \\ ${ }^{1}$ School of Law, Jimei University, 361021 Jimei District, Xiamen, China \\ ${ }^{2}$ School of Business Administration, Hubei University of Economics, 430205 Jiangxia District, Wuhan City, Hubei Province, China
}

\begin{abstract}
China's coastal cities have vigorously promoted environmental protection of urban garbage classification system, and the construction process of renewable resources recovery system is still in a state of slow development. This study starts from the residents' awareness and daily behavior of renewable resources utilization. Through in-depth interviews and questionnaire survey, we can get a better grasp of the awareness and behavior of renewable resources recovery from the interviews, and make more systematic and comprehensive statistics on residents' understanding of renewable resources related issues from the questionnaire. In addition to the difficulties in management, capital, personnel and technology, urban residents are not active enough in recycling renewable resources in their daily life. Therefore, renewable resources are a new kind of human resources. The rational use of "waste" can not only solve the environmental problems, but also solve the resource problems, so as to achieve a win-win situation. In today's society, the concept of circular economy ecosystem has been gradually introduced into the mechanism of economic operation. The construction of renewable resources recycling system has become an important part of circular economy strategy.
\end{abstract}

\section{Introduction}

Renewable resources are a new resource for mankind. The rational use of "waste" can not only solve environmental problems, but also solve resource problems, achieving a mutually beneficial and win-win situation.

The existence of various resources has become a necessary guarantee for human survival on the earth. With the development of society and economy, in order to meet the ever-increasing needs of human life, it has become inevitable to increase the development and utilization of resources, and even adopt predatory development methods. Faced with the impact of depleted resources on the future survival of mankind, the entire society needs to be changed (Liet al., 2008). Facing the current global resource and environmental crisis, scholars have proposed a new economic development model, namely circular economy. Compared with the traditional economy, it forms a closed cycle metabolism mode through resource circulation, which imitates the metabolism mode of the natural ecosystem to a large extent (Xu, 2011).

China's renewable resource recycling system started in the waste material recycling industry in the last century, and now has a recycling system including: recycling, sorting, sorting, transportation, resource processing, reuse, and sales (Feng and $\mathrm{Lu}, 2008$ ). In the recycling system of urban residents' renewable resources, residents are the front end, so it is relatively lacking in enthusiasm at present, and there are still problems in the construction of the recycling system.

In order to gradually improve the residents' renewable resource recycling network system, China successively launched two batches of pilot cities on the construction of a renewable resource recycling system in 2006 and 2009. A total of 55 pilot cities and 11 regional distribution bases were identified, basically covering In addition, municipalities directly under the Central Government, cities separately listed in the plan, and provincial capitals(Liu and Yang, 2016). A "Trinity" recycling model centered on recycling points, sorting centers, and distribution markets has initially formed. Residents sort the garbage to be processed into garbage bags and throw them to the designated production facility where they live. After being collected by the sanitation department on time, they are sorted, cleaned and transported. After simple compression, they are directly sent to the designated garbage landfill for harmless filling. Buried; the second is recycling, some of the higher-value waste passes through some recycling pipelines and enters the renewable resource recycling system (Xu et al., 2017).

The various definitions of circular economy theory basically revolve around "ecology", "production technology" and "new economic form". According to the "space ship theory" proposed by Kenneth Boulding (1966), it is recognized by the academic circles as the current cycle. The origin of economic thought. It is believed that this

* Corresponding author: scftitan@yahoo.com.tw 
spacecraft is a completely isolated and enclosed space from the outside world, which is completely maintained by its own material and energy. However, its resources are limited, so it must be recycled, so there is almost no waste in this space. This theory is the representative of the early circular economy theory (Jarrett, 1966). It is proposed that the theory of circular economy has not yet truly formed a system. The essence of circular economy is that the extension of "economy" is related to the relationship between "society", "environment" and "economy" (Lu and Chen, 2014). If the development of circular economy is viewed from the three levels of macro, meso, and micro, there are three development models, namely, small cycle mode (cleaner production of enterprises), medium cycle mode (industrial park circular economy) and large cycle mode (recycling society) (Zhang and Liu, 2016).

\section{Methods}

In recent years, with the continuous development of Chinese cities, urban population growth, increasing economic standards, and the rapid progress of urbanization, the amount and structure of urban residents' waste resources have also changed. Since "ecological civilization" was put forward, the recycling and treatment of urban renewable resources based on the concepts of sustainable development, circular economy, and beautiful cities have gradually received much attention. How to better build the field of renewable resource recycling is the goal we must keep exploring.

\subsection{Research Purpose and Significance}

This research is based on the theory of circular economy, comprehensively using methods such as in-depth interviews and questionnaire surveys, starting from the perspective of urban residents, analyzing and summarizing relevant data obtained through practice, and analyzing and researching these problems to solve the current situation of renewable resource recycling management.

\subsection{Research Method and Process}

Combining in-depth interviews and questionnaire surveys for data collection and analysis, through the interaction of interviews and questionnaires, to gain insights into the interviewee's own awareness and thoughts on recycling of renewable resources (Table 1), and whether the behavior is carried out in daily life Understand the related reasons of the recycling and treatment practices of renewable resources, and make relevant analysis of residents' daily behaviors. Therefore, this study conducted interviews with random residents and then explored related issues.

Table 1. Basic Information of the Interviewee

\begin{tabular}{|c|c|c|c|c|c|c|}
\hline No. & Respondents & Gender & Occupation & Age & Interview Date & $\begin{array}{c}\text { Interview Time } \\
\text { (minutes) }\end{array}$ \\
\hline A & Zhao** & M & Staff & $31-45$ & 2019.5 .13 & $05: 34$ \\
\hline B & Zhang** & F & Staff & $31-45$ & 2019.5 .15 & $06: 20$ \\
\hline C & Zhou** & F & Staff & $46-60$ & 2019.7 .23 & $07: 39$ \\
\hline D & Chen** & M & Staff & $31-45$ & 2019.7 .30 & $10: 49$ \\
\hline E & Lin** & F & Staff & $18-30$ & 2019.8 .05 & $13: 04$ \\
\hline F & King** & M & Staff & $18-30$ & 2019.8 .19 & $09: 13$ \\
\hline G & Liu** & M & Freelance & $31-45$ & 2019.9 .03 & $07: 52$ \\
\hline H & Zhao** & F & Sanitation & $46-60$ & 2019.9 .10 & $06: 22$ \\
\hline I & Liu** & F & Staff & $33-45$ & 2019.10 .01 & $08: 31$ \\
\hline J & Guo** & M & Retirees & Over 60 & 2019.10 .02 & $13: 07$ \\
\hline K & Liu** & F & Student & Under 18 & 2019.10 .03 & $06: 22$ \\
\hline L & Zeng** & M & Student & $18-30$ & 2019.10 .03 & $05: 47$ \\
\hline M & Lin** & F & Student & $18-30$ & 2019.10 .22 & $08: 33$ \\
\hline N & Chen** & F & Student & $18-30$ & 2019.10 .23 & $09: 20$ \\
\hline O & Chen** & F & Student & $18-30$ & 2019.10 .23 & $11: 55$ \\
\hline
\end{tabular}

\section{Results}

The interviewees basically have a certain understanding of the cognition of renewable resources. In terms of information understanding channels, the media is the main source of information, and the Internet media is the main source of information. In the daily recycling situation, selective recycling is used. The situation accounted for the majority. In terms of the convenience of daily recycling, more than half of the respondents near the community did not have a recycling outlet. Among them, the convenience of daily recycling has a lot to do with whether there are recycling outlets nearby. Combining the six research directions of the questionnaire, conduct further research 
on the recycling of residents' renewable resources, and integrate, compare, and supplement the questionnaire data with the interview content (Table 2).

Table 2. Residents' Awareness of Recycling of Renewable Resources

Residents' perception of renewable resources

\begin{tabular}{|l|l|c|c|}
\hline \multicolumn{1}{|c|}{ Question } & \multicolumn{1}{c|}{ Subgroup } & N & $\%$ \\
\hline $\begin{array}{l}\text { Do you know } \\
\text { what renewable } \\
\text { resources are? }\end{array}$ & Totally no idea & 1 & $1.04 \%$ \\
\cline { 2 - 4 } & $\begin{array}{l}\text { Heard, but don't } \\
\text { understand }\end{array}$ & 22 & $22.90 \%$ \\
\cline { 2 - 4 } & Basically know & 63 & $65.60 \%$ \\
\cline { 2 - 4 } & Know, very clear & 10 & $10.40 \%$ \\
\hline
\end{tabular}

\section{Daily resource recovery of resident}

\begin{tabular}{|c|c|c|c|}
\hline Question & Subgroup & $\mathbf{N}$ & $\%$ \\
\hline \multirow{4}{*}{$\begin{array}{l}\text { Do you usually } \\
\text { pay attention to } \\
\text { the accumulation } \\
\text { and recycling of } \\
\text { renewable } \\
\text { resources? }\end{array}$} & $\begin{array}{l}\text { No, dispose of it with } \\
\text { ordinary garbage. }\end{array}$ & 22 & $22.92 \%$ \\
\hline & $\begin{array}{l}\text { Yes, but only for } \\
\text { high-value ones. } \\
\text { (Such as: second- } \\
\text { hand home } \\
\text { appliances, etc.) }\end{array}$ & 23 & $24.00 \%$ \\
\hline & $\begin{array}{l}\text { Yes, but only for } \\
\text { high-value or large } \\
\text { quantities. (Such as a } \\
\text { large number of } \\
\text { magazines, etc.) }\end{array}$ & 34 & $35.42 \%$ \\
\hline & $\begin{array}{l}\text { Yes, I collect } \\
\text { everything that is } \\
\text { basically recyclable. }\end{array}$ & 17 & $17.70 \%$ \\
\hline
\end{tabular}

Residents' attitude towards publicity and guidance

\begin{tabular}{|c|c|c|c|}
\hline Question & Subgroup & $\mathbf{N}$ & $\%$ \\
\hline \multirow{4}{*}{$\begin{array}{l}\text { Do you think it } \\
\text { is necessary to } \\
\text { promote the } \\
\text { recycling of } \\
\text { renewable } \\
\text { resources in the } \\
\text { community? }\end{array}$} & Totally unnecessary & 4 & $4.17 \%$ \\
\hline & Doesn't matter & 23 & $23.96 \%$ \\
\hline & $\begin{array}{l}\text { It is necessary to } \\
\text { improve people's } \\
\text { environmental } \\
\text { awareness }\end{array}$ & 54 & $56.25 \%$ \\
\hline & $\begin{array}{l}\text { Very necessary, I } \\
\text { always hope to } \\
\text { promote }\end{array}$ & 15 & $15.63 \%$ \\
\hline
\end{tabular}

Residents' attitudes towards online resource trading

\begin{tabular}{|l|l|c|c|}
\hline \multicolumn{1}{|c|}{ Question } & \multicolumn{1}{|c|}{ Subgroup } & N & \% \\
\hline $\begin{array}{l}\text { Do you think that if } \\
\text { community recycling of } \\
\text { renewable resources is } \\
\text { combined with online } \\
\text { platforms (such as } \\
\text { mobile phone software, } \\
\text { online renewable } \\
\text { resource trading), will } \\
\text { you use it? }\end{array}$ & \begin{tabular}{l} 
Yeason is: \\
\cline { 2 - 4 }
\end{tabular} & 19 & $19.80 \%$ \\
\hline
\end{tabular}

Residents believe that the current renewable resource operation problems

\begin{tabular}{|c|l|c|}
\hline \multicolumn{1}{|c|}{ Question } & \multicolumn{1}{|c|}{ Subgroup } & N \\
\hline $\begin{array}{l}\text { Do you think } \\
\text { there are any }\end{array}$ & $\begin{array}{l}\text { The government did not } \\
\text { promote enough. }\end{array}$ & 47 \\
\hline
\end{tabular}

\begin{tabular}{|l|l|c|}
\hline $\begin{array}{l}\text { problems with } \\
\text { the renewable } \\
\text { resource } \\
\text { recovery } \\
\text { system? } \\
\text { [Multiple } \\
\text { choices }]\end{array}$ & $\begin{array}{l}\text { The residents do not have this } \\
\text { awareness. }\end{array}$ & 60 \\
\cline { 2 - 3 } & $\begin{array}{l}\text { The technology of renewable } \\
\text { resource recovery is } \\
\text { insufficient and the model is } \\
\text { not perfect. }\end{array}$ & 56 \\
\cline { 2 - 3 } & $\begin{array}{l}\text { There is no guarantee of the } \\
\text { rules and regulations of } \\
\text { systematic recycling of } \\
\text { renewable resources. }\end{array}$ & 57 \\
\cline { 2 - 3 } & $\begin{array}{l}\text { There are too few recycling } \\
\text { points, and I don't know } \\
\text { where to trade. }\end{array}$ & 62 \\
\cline { 2 - 3 } & \begin{tabular}{l} 
Other: \\
\hline
\end{tabular}
\end{tabular}

Residents' expectations for the future of recycling of renewable resources

\begin{tabular}{|c|c|c|c|}
\hline Question & Subgroup & $\mathbf{N}$ & $\%$ \\
\hline \multirow{4}{*}{$\begin{array}{l}\text { What is your } \\
\text { opinion on the } \\
\text { future } \\
\text { development of } \\
\text { renewable } \\
\text { resource } \\
\text { recycling? }\end{array}$} & $\begin{array}{l}\text { Not optimistic, there } \\
\text { is still a long way to } \\
\text { go. }\end{array}$ & 8 & $8.33 \%$ \\
\hline & $\begin{array}{l}\text { I don't know, the } \\
\text { future is uncertain. }\end{array}$ & 27 & $28.13 \%$ \\
\hline & General & 41 & $42.71 \%$ \\
\hline & Optimistic about & 20 & $20.83 \%$ \\
\hline
\end{tabular}

In the previous questionnaire statistics, only $1.04 \%$ of the sample did not understand renewable resources and recycling at all. During the interview, the H-number interviewer was very unfamiliar with the term renewable resources at the beginning of the interview, but as the interview progressed, she could understand that in her daily life, she had a lot to do with the recycling and reuse of resources. She has a passion for recyclable resources, she basically never misses it. Of course, this is partly due to the economic drive and her own professional habits.

During the interview process, the daily behavior of residents' recycling is a must-understand issue. According to the collected results in the overall profile, most interviewees will selectively recycle, and only a few respondents said they will recycle all or not. This is also consistent with the conclusion drawn from the previous questionnaire statistics. Regarding this question in the interview, the answer of the respondents who said to recycle or not to recycle was summed up as "trouble". In the dialogue with the interviewees on this aspect, we can clearly feel that they have obviously different attitudes and behaviors towards recycling. For respondents who basically do not recycle, their main reason is that the return is too troublesome and the convenience of nearby recycling is also related to some extent. Most of them prefer to sort and recycle the back-end, and most of them are not so concerned about the value of recycled products. I care more about whether it will cause inconvenience to my daily life. For the respondents of selective recycling, they usually choose recycling based on value. They are more concerned about the value of recycled products. Of course, the inconvenience of daily recycling also hinders their related recycling. For all residents who recycle, there are usually related recycling outlets to support public construction. In daily life, they also have better recycling habits. The combination of individuals and society promotes their recycling of renewable resources. 
In the questionnaire survey data, more than $70 \%$ of people want to conduct community publicity and guidance. In the interview, half of them actively talked about publicity and guidance during the interview. Some interviewees even believed that the current recycling of renewable resources The main reason for the predicament is insufficient publicity and guidance to the residents. It can also be seen from the interview that the publicity and guidance of the places where the interviewees live is not in place, or even no publicity. When the interviewees mentioned this publicity-related issue, several of them could feel their emotional upswing. They said that the recycling of renewable resources is not ideal. It is entirely due to the inaction of the relevant departments in guiding residents to recycle resources. They believe that more residents are completely ignorant of this system, so they will not and have no obligation to participate in it. On the other hand, behind the emotions, some interviewees can also feel the concern about resource recovery.

In the discussion of this aspect of publicity, each interviewee has his own unique insights. Except for those not publicized in their own communities, in communities with publicity guidance, one can feel whether it is the broadening of the awareness channel of resource recycling or the daily recycling. In the interaction of time, we have truly realized the important role of publicity in the implementation of residents' renewable resource recovery.

Regarding the "Internet + renewable resources" model, in the interview, residents were simply asked about their thoughts on online transactions. For online transactions, each respondent has his own consideration. In the questionnaire survey, $80 \%$ of the respondents were Supporting online transactions, in an increasingly information-based society, it is not difficult to see through various research reports on the "feasibility of implementing the online transaction system" and "the effect of pilot residents' implementation" in recent years. In the renewable resource recycling market, scholars and experts hope to reorganize the market through the construction of an online platform. Respondents A and F believe that one of the prerequisites for it is whether it can bring us convenience or not, whether it is on-site, and the quantity and price of recycling are all factors to be considered. Respondent D is more concerned about whether the online trading platform can be upgraded in a known market environment, and whether it can accommodate all kinds of renewable resource recycling in life, but this is important for the current recycling market. That said, there are obviously some difficulties, and this requires more than just the development of the enterprise. In addition to the main types of recycling, for the development of other niche recycling markets, it is a place worthy of our management.

For people in different living environments, their feelings are definitely different. Interviewee B mentioned many times during the interview that it is difficult to recycle large items. It can be seen that she hopes that the problem can be improved; Of course, it can also be seen from the interview that many interviewees are not satisfied with the current publicity and guidance; in terms of residents' awareness, the interviewees often expressed their own or community residents' inadequacy in this respect. Respondent $\mathrm{G}$ put forward a new entry point on this issue, in addition to the inertia of public construction residents, the negative impact of the environment and culture.

\section{Discussion}

The research on the recycling of residents' renewable resources uses a combination of questionnaires and interviews, hoping to better find out the problems of residents' recycling of renewable resources at the emerging stage. This research is explained separately in the interview analysis and the questionnaire data. After interviews, it can be learned that the current renewable resource recycling market is not only imperfect but also relatively chaotic. It is recommended that when we study related fields in the future, we can focus on the market construction in renewable resource recycling. Improvement is the priority, which can further improve the current situation of the resource recovery market. For the current downturn in the renewable resource market, the government should provide subsidies to enterprises related to renewable resource recovery, especially for lowvalue recyclable resources. It is necessary to establish a management system for low-value recyclable resources.

\section{Conclusions}

Although the general residents' awareness of resource recovery is not sufficient, there are generally no obstacles. The analysis shows that the level of awareness will play a guiding role in the corresponding behavior of residents, but the daily resource recovery of residents is not Relying on these alone, it is a complex reflection. For relatively low-level residents, economic value can more drive the enthusiasm of renewable resource recovery. The general population, awareness-guided attraction is more mainstream for residents' renewable resource recovery than the attraction of value. In the cognitive channel, At this stage, the comprehensive publicity of recycling of renewable resources should strengthen the role of the Internet and education. Depending on each resident's personality, habits, place of residence, and other conditions, there are many different feelings.

\section{References}

1. Li, J. W., Hu, Y. H., Hu, R. C. (2008) The status quo, existing problems and countermeasures of renewable resource development and utilization in China. Environment and Development, 1, 53-56.

2. Xu, J. P. (2011) A Research on the Recycling and Reusing Network of the Renewable Resources. Shanghai: Donghua University.

3. Feng, H. J., Lu, M. Z. (2008) Thoughts on the development of renewable resources industry. Environment and Sustainable Development, 1, 49-51.

4. Liu, L. C., Yang,J. Z. (2016) Study and discussion of ' $3 R$ ' principle, part 2: recycling is the soul of reutilization. Recyclable Resources and Circular 
Economy, 9(9), 16-19.

5. Xu, B., Gao, Y., Wang, K. W., Cheng, F. L., Zheng, W. K. (2017) Exploration on the network of living garbage in Xi'an City. Recyclable Resources and Circular Economy, 10(1), 26-32.

6. Jarrett, H. (1996) Environmental Quality in a Growing Economy. Balti-more: The Johns Hopkins University Press.

7. Lu, X., Chen, X. P. (2014) A Review of circular economy. China Population, Resources and Environment, 24(S2), 204-208.

8. Zhang, Z. H., Liu, F. (2016) The main development mode and prospect of China's circular economy .Economic Outlook the Bohai Sea, 9, 3-5. 